\title{
Heat-Treatment of Bovine Colostrum. II: Effects of Heating Duration on Pathogen Viability and Immunoglobulin G
}

\author{
S. Godden, ${ }^{\star 1}$ S. McMartin, ${ }^{\star}$ J. Feirtag,† J. Stabel,‡ R. Bey,§ S. Goyal,§ L. Metzger,† \\ J. Fetrow, ${ }^{*}$ S. Wells, ${ }^{*}$ and H. Chester-Jones\| \\ *Department of Veterinary Population Medicine, and \\ †Department of Food Science and Nutrition, University of Minnesota, St. Paul 55108 \\ fUSDA, ARS, National Animal Disease Center, Ames, IA 50010 \\ $\S$ Department of Veterinary and Biomedical Sciences, and \\ |Department of Animal Science, University of Minnesota, St. Paul 55108
}

\section{ABSTRACT}

Batches (30-L) of first-milking bovine colostrum, inoculated with Mycoplasma bovis $\left(10^{8} \mathrm{cfu} / \mathrm{mL}\right)$, Listeria monocytogenes $\left(10^{6} \mathrm{cfu} / \mathrm{mL}\right)$, Escherichia coli $\mathrm{O} 157: \mathrm{H} 7$ $\left(10^{6} \mathrm{cfu} / \mathrm{mL}\right)$, Salmonella enteritidis $\left(10^{6} \mathrm{cfu} / \mathrm{mL}\right)$, and Mycobacterium avium subsp. paratuberculosis (Map; $10^{3} \mathrm{cfu} / \mathrm{mL}$ ), were heat-treated at $60^{\circ} \mathrm{C}$ for $120 \mathrm{~min}$ in a commercial on-farm batch pasteurizer system. Duplicate $50-\mathrm{mL}$ subsamples of colostrum were collected at 15-min intervals throughout the heat-treatment process for the purpose of bacterial culture and for measurement of IgG concentration $(\mathrm{mg} / \mathrm{mL})$ and antibody activity $\left[\log _{2}\right.$ (bovine viral diarrhea virus type 1 serum neutralization titer)]. Four replicate batches of colostrum were run for each of the 5 pathogens studied. There was no effect of heating moderate- to high-quality colostrum at $60^{\circ} \mathrm{C}$ for at least $120 \mathrm{~min}$ on mean IgG concentration $($ pre $=60.5 \mathrm{mg} / \mathrm{mL}$; post $=59.1 \mathrm{mg} / \mathrm{mL}$ ). Similarly, there was no effect of heat-treatment on the mean $\log _{2}$ bovine viral diarrhea virus type 1 serum neutralization titer $($ pre $=12.3$; post $=12.0$ ). Viable $M$. bovis, L. monocytogenes, E. coli O157:H7, and $S$. enteritidis added to colostrum could not be detected after the colostrum was heat-treated at $60^{\circ} \mathrm{C}$ for 30 min. Average bacteria counts showed that Map was not detected when batches were heated at $60^{\circ} \mathrm{C}$ for $60 \mathrm{~min}$. Although the authors believe that heat-treating colostrum at $60^{\circ} \mathrm{C}$ for $60 \mathrm{~min}$ should be sufficient to eliminate Map from colostrum in most situations, further research is needed to determine whether these findings may be replicated, given that variability was observed in Map culture results.

Key words: colostrum, pasteurization, pathogen, immunoglobulin

Received March 3, 2006.

Accepted April 20, 2006.

${ }^{1}$ Corresponding author: godde002@umn.edu
INTRODUCTION

First-milking colostrum is an important source of nutrients and an immediate source of passively absorbed maternal antibodies, which are critical in the protection of the newborn calf against infectious diseases in the first weeks and months of life (Davis and Drackley, 1998). However, colostrum can also represent one of the earliest potential exposures of dairy calves to infectious agents, including Mycoplasma spp. (Walz et al., 1997), Mycobacterium avium subsp. paratuberculosis (Map; Streeter et al., 1995), Escherichia coli (Clark et al., 1989; Steele et al., 1997), Salmonella spp. (McEwen et al., 1988; Giles et al., 1989; Steele et al., 1997), Listeria monocytogenes (Farber et al., 1988; Steele et al., 1997), and Campylobacter spp. (Lovett et al., 1983; Steele et al., 1997). For example, Map has been recovered from the colostrum of $22.2 \%$ of clinically normal but Mapinfected cows (36\% of heavy fecal shedders; $16 \%$ of light fecal shedders; Streeter et al., 1995). Some of these pathogens can act directly to produce costly short-term consequences (e.g., neonatal enteritis or septicemia), whereas others may cause longer term losses (e.g. Johne's disease caused by Map). It has also been suggested that the presence of bacteria in the small intestine at the time of colostrum arrival could indirectly harm calf health by interfering with systemic absorption of Ig molecules (James and Polan, 1978; James et al., 1981; Staley and Bush, 1985), thus contributing to the failure of passive transfer. In one observational study of commercial dairies, Poulsen et al. (2002) reported that $82 \%$ of colostrum samples collected exceeded the industry goal of $100,000 \mathrm{cfu} / \mathrm{mL}$ total plate count, suggesting that the feeding of contaminated colostrum is a common occurrence on commercial dairy farms (McGuirk and Collins, 2004).

On-farm pasteurization of colostrum has been suggested as one possible control measure to reduce or eliminate transfer of colostrum-borne pathogens to dairy calves. However, early research on pasteurizing colostrum at $72^{\circ} \mathrm{C}$ for $15 \mathrm{~s}$ using a commercial HTST 
continuous-flow pasteurization method reported 25 to $30 \%$ reduction in IgG concentration $(\mathrm{mg} / \mathrm{mL})$ plus unacceptable feeding characteristics (Green et al., 2003; Stabel et al., 2004). Batch pasteurization of colostrum at conventional times and temperatures commonly used for pasteurizing milk $\left(63^{\circ} \mathrm{C} \times 30 \mathrm{~min}\right)$ produced milder increases in viscosity but still resulted in 25 to $30 \%$ reduction in IgG concentration (Godden et al., 2003; Green et al., 2003). In light of this knowledge, the goal was set to develop a longer and lower-temperature method for heat-treating colostrum that would preserve important colostral antibodies and prevent viscosity changes while still achieving good pathogen kill. In an earlier study, we learned that 50-mL aliquots of bovine colostrum could be heat-treated in a Rapid Visco Analyzer (Newport Scientific, Warriewood, Australia) at $60^{\circ} \mathrm{C}$ for as long as 120 min without affecting either colostrum viscosity or IgG concentration (McMartin et al. 2006). The objectives of this study were to describe the effects of heat-treatment on IgG concentration and activity, and to describe the duration of heating necessary to eliminate important pathogens when heating large volumes of bovine colostrum to $60^{\circ} \mathrm{C}$ in a commercial on-farm batch pasteurization system.

\section{MATERIALS AND METHODS}

\section{Inoculation and Heat Treatment of Colostrum with Mycoplasma bovis, L. monocytogenes, E. coli 0157:H7, and Salmonella enteritidis}

First-milking colostrum was previously collected from Holstein cows on one commercial dairy farm and stored at $-20^{\circ} \mathrm{C}$ for 2 to $16 \mathrm{wk}$ prior to use in this study. Thawed colostrum at $20^{\circ} \mathrm{C}$ was pooled to create a unique 30-L batch, transferred into a commercial on-farm batch pasteurization system (DairyTech Inc., Windsor, $\mathrm{CO}$ ), and then inoculated with the following 4 pathogens to reach the final indicated concentrations: $M$. bovis $\left(10^{8} \mathrm{cfu} / \mathrm{mL}\right), L$. monocytogenes $\left(10^{6} \mathrm{cfu} / \mathrm{mL}\right), E$. coli $\mathrm{O} 157: \mathrm{H} 7\left(10^{6} \mathrm{cfu} / \mathrm{mL}\right)$, and $S$. enteritidis $\left(10^{6} \mathrm{cfu} /\right.$ $\mathrm{mL}$ ). The batch of colostrum was then heated over a 30 -min period to reach the target temperature of $60^{\circ} \mathrm{C}$, held at $60^{\circ} \mathrm{C}$ for $120 \mathrm{~min}$, and then cooled over a 15 min period to reach $38^{\circ} \mathrm{C}$. The colostrum was agitated continuously throughout the heat-treatment process. Duplicate $50-\mathrm{mL}$ samples were aseptically collected from the batch immediately prior to inoculation, immediately postinoculation, on reaching the target temperature of $60^{\circ} \mathrm{C}$, and thereafter at 15 -min intervals throughout the entire heat-treatment process until the colostrum was cooled to $38^{\circ} \mathrm{C}$. These samples were aseptically collected into sterile $50-\mathrm{mL}$ centrifuge tubes
(Corning Inc., Corning, NY) and then placed immediately on ice until completion of the heat-treatment process. Four unique replicate batches of colostrum were run containing the aforementioned pathogens.

Chilled colostrum samples were submitted immediately for microbial culture for M. bovis, L. monocytogenes, S. enteritidis, and E. coli O157:H7. Duplicate samples intended for measurement of IgG concentration and activity were frozen at $-20^{\circ} \mathrm{C}$ for 2 to $4 \mathrm{wk}$ and then submitted for testing at the Veterinary Diagnostic Laboratory at the University of Minnesota (St. Paul, $\mathrm{MN})$.

\section{Inoculation and Heat Treatment of Colostrum with Map}

As was described for previous batches, thawed bovine colostrum at $20^{\circ} \mathrm{C}$ was pooled to create a unique 30 $\mathrm{L}$ batch, transferred into a commercial on-farm batch pasteurization system (DairyTech Inc.), and then inoculated with Map to reach a final concentration of $10^{3} \mathrm{cfu} /$ $\mathrm{mL}$. The heat-treatment and sampling procedures were the same as described for the other 4 pathogens. All samples were stored at $-20^{\circ} \mathrm{C}$ and then transported to USDA-ARS, National Animal Disease Center (Bacterial Diseases of Livestock Research Unit, Ames, IA), where they were tested for Map by bacterial culture and by PCR.

As for the other pathogens, 4 unique replicate batches of colostrum were run for Map. However, one difference in methodology for heat-treatment of the $4 M a p$-inoculated colostrum batches should be noted. For the first 2 batches of Map-inoculated colostrum, early results for Map culture showed that both the positive and negative control samples were contaminated when cultured on slants of Herrold's egg yolk medium (HEYM), precluding the authors' ability to demonstrate the presence of Map in the positive control samples. Nonetheless, the authors believe that it is still valid to report the results from these first 2 batches because Map was clearly cultured (and confirmed with PCR) from the third, fourth, and fifth samples (collected at 0,15 , and 30 min at $60^{\circ} \mathrm{C}$, respectively), after heat-treatment had effectively removed all other contaminants from the colostrum. However, in an effort to remove these contaminants prior to inoculating the batch with Map, the third and fourth batches of colostrum were pre-heattreated at $60^{\circ} \mathrm{C}$ for $60 \mathrm{~min}$ and then cooled to $20^{\circ} \mathrm{C}$ before inoculating the batch with Map. After inoculation, the 120 -min heat-treatment process at $60^{\circ} \mathrm{C}$, and the associated sample collection process, was then completed in full as described above. The authors were comfortable in taking this approach for the last $2 \mathrm{Map}$ inoculated batches because previous research has 
shown that the pre-heat-treatment process does not change the fluid characteristics of the colostrum in any way that should alter the results of heat-treating Map in this pre-heat-treated colostrum (McMartin et al., 2006).

\section{Culture of L. monocytogenes, E. coli 0157:H7, $S$. enteritidis, and M. bovis from Colostrum}

The FDA Bacteriological Analytical Manual methods were used to confirm the presence or absence of viable bacteria except that the media for Salmonella consisted of tryptic soy agar (40 g), yeast extract (6 g), ferric ammonium citrate $(0.8 \mathrm{~g})$, sodium thiosulfate $(6.8 \mathrm{~g})$, and sodium pyruvate $(1 \mathrm{~g})$ in $1 \mathrm{~L}$ of distilled water $(\mathrm{V}$. Burgula and S. Tatini, unpublished data). Serial 10fold dilutions of the samples made in $0.1 \%$ peptone water were inoculated in appropriate media using the spread-plate technique. The plates were incubated at $37^{\circ} \mathrm{C}$ for 24 to $48 \mathrm{~h}$ and examined for the presence or absence of the pathogens. For M. bovis, serial 10-fold dilutions of colostrum were made in sterile Mycoplasma broth and $200 \mu \mathrm{L}$ of each dilution was plated on 3 sterile Mycoplasma agar plates. The inoculated plates were incubated at $37^{\circ} \mathrm{C}$ in $10 \%$ carbon dioxide for $6 \mathrm{~d}$ prior to examination for the presence of bacterial growth.

\section{Culture of Map from Colostrum}

For the culture of Map, approximately $10 \mathrm{~mL}$ of each colostrum sample was transferred to a sterile $15-\mathrm{mL}$ conical polypropylene tube and centrifuged at $739 \times g$ for $30 \mathrm{~min}$ at $4^{\circ} \mathrm{C}$. After centrifugation, the whey was decanted and the pellet and cream were resuspended in $2 \mathrm{~mL}$ of $0.75 \%$ hexadecylpyridinium chloride (Sigma Chemical Co., St. Louis, MO) prepared in $50 \%$ brain heart infusion broth (Becton-Dickinson, Franklin Lakes, NJ). Samples were then incubated at $39^{\circ} \mathrm{C}$ for $5 \mathrm{~h}$ followed by centrifugation at $1,160 \times g$ for $20 \mathrm{~min}$ at $4^{\circ} \mathrm{C}$. Pellets were resuspended in $1 \mathrm{~mL}$ of antibiotic brew $(100 \mu \mathrm{g} / \mathrm{mL}$ of nalidixic acid, $100 \mu \mathrm{g} / \mathrm{mL}$ of vancomycin, and $50 \mu \mathrm{g} / \mathrm{mL}$ of amphotericin B; Sigma Chemical Co.) and incubated for $24 \mathrm{~h}$. Samples were diluted 1:10 in $0.15 M$ PBS (pH 7.4), and $200 \mu \mathrm{L}$ of the $1: 10$ dilution was inoculated onto 2 agar slants of HEYM containing mycobactin J ( $2 \mathrm{mg} / \mathrm{L}$; Allied Monitor, Fayetteville, MO), nalidixic acid ( $50 \mu \mathrm{g} / \mathrm{mL})$, and vancomycin $(50 \mu \mathrm{g} / \mathrm{mL})$. Samples were also inoculated onto 2 slants of commercially prepared HEYM. During incubation at $39^{\circ} \mathrm{C}$ for $12 \mathrm{wk}$, tubes were monitored for bacterial growth at 4,8 , and 12 wk. Colony growth was confirmed by PCR as described below.

\section{Extraction of Map DNA Using PCR Analysis}

A 500- $\mu \mathrm{L}$ aliquot of each colostrum sample (pre- and postinoculation and heating) was transferred to a sterile $1.5-\mathrm{mL}$ microcentrifuge tube and vortexed briefly. Samples were centrifuged at $18,237 \times g$ for $15 \mathrm{~min}$ and the supernatant was decanted. Proteinase K $(1 \mathrm{mg} / \mathrm{mL}$; Sigma Chemical Co.) was added to each sample and incubated in a $50^{\circ} \mathrm{C}$ shaker water bath overnight. Following incubation, $22 \mu \mathrm{L}$ of Tris-EDTA-NaCl buffer (50 $\mathrm{m} M$ Tris, $100 \mathrm{~m} M$ EDTA, and $150 \mathrm{~m} M \mathrm{NaCl}$; $\mathrm{pH}$ 8.0) and $10 \mu \mathrm{L}$ of $0.4 M \mathrm{NaOH}$ was added to each sample and the tubes were vortexed. The tubes were then placed in a heating block $\left(100^{\circ} \mathrm{C}\right)$ in water and boiled for $30 \mathrm{~min}$. After cooling, samples were subjected to a phenol-chloroform-isoamyl alcohol (25:24:1; Amresco, Solon, OH) extraction and overnight precipitation in $100 \%$ ethanol; DNA pellets were resuspended in sterile water and stored at $-20^{\circ} \mathrm{C}$.

To validate Map growth on HEYM agar after $12 \mathrm{wk}$ of culture, suspect colonies were scraped with a sterile loop and placed into $250 \mu \mathrm{L}$ of $1 \times$ Tris-EDTA buffer in a $1.5-\mathrm{mL}$ microcentrifuge tube. Tubes were placed in a heating block $\left(100^{\circ} \mathrm{C}\right)$ in water and boiled for $10 \mathrm{~min}$. After cooling to room temperature, $4 \mu \mathrm{L}$ of RNase was added to each tube and samples were stored at $-20^{\circ} \mathrm{C}$ until PCR was performed.

The DNA was amplified using a nested PCR protocol previously described for milk samples (Stabel and Lambertz, 2004). For the first amplification reaction, forward and reverse primers (5'-GTTCGGGGCCGTCGC TTAGG-3' and 5'-GAGGTCGATCGCCCACGTGA-3') were used to amplify a 400-bp region of the insertion element IS900. A second amplification reaction further amplified the product of the first reaction, using internal forward and reverse primers (5'-GCTTAGGCTTC GAATTGCC-3' and 5'-CTCCGTAACCGTCATTGTCC$3^{\prime}$ ) and resulted in a final product of $194 \mathrm{bp}$. After amplification, DNA was electrophoresed in a $4 \%$ agarose gel (Reliant Gel Systems, FMC Bioproducts, Rockland, $\mathrm{ME}$ ), containing ethidium bromide in Tris-borateEDTA buffer (89 $\mathrm{m} M$ Tris, $89 \mathrm{~m} M$ boric acid, and 2 $\mathrm{m} M$ EDTA), and bands were visualized using a UV transilluminator (Bio-Rad, Hercules, CA). A positive control DNA sample (Map DNA) was included in each PCR run and on each gel for assay verification. A negative control consisting of buffer only was run each time to verify lack of cross-contamination of samples.

\section{Measurement of IgG Concentration and Activity in Colostrum}

Analysis of colostrum samples for total IgG concentration $(\mathrm{mg} / \mathrm{mL})$ was completed using a turbidometricimmunoassay (instrument: Olympus AU400e; Olym- 
pus America Inc., Melville, NY; reagents: Midland Bioproducts Corp., Boone, IA). The turbidometric-immunoassay is a highly sensitive automated lateral-flow immunoassay that directly measures turbidity of the antigen-antibody complex, producing accurate IgG measures as compared with the more time-consuming and labor-intensive radial immunodiffusion method (Etzel et al., 1997; McVicker et al., 2002). A paired $t$ test was used to contrast the colostrum IgG concentration $(\mathrm{mg} / \mathrm{mL})$ measured at each of the 15-min interval sampling points against the original IgG concentration measured in sample number 2 (postinoculation sample at $20^{\circ} \mathrm{C}$ ). Statistical significance was established at $P$ $<0.05$.

A microtitration serum neutralization (SN) assay was used to evaluate antibody activity in colostrum samples. Frozen samples of colostrum were thawed at room temperature and then centrifuged at 28,800 $\times g$ for $2 \mathrm{~h}$. Clear whey was used as the starting material for the detection of antibodies against bovine viral diarrhea virus type 1 (BVDV-1) using the SN test. Serial 2fold dilutions of whey were made in modified Eagle's medium with Earle's salts, $150 \mathrm{IU} / \mathrm{mL}$ of penicillin, 150 $\mu \mathrm{g} / \mathrm{mL}$ of streptomycin, $50 \mu \mathrm{g} / \mathrm{mL}$ of neomycin, and 1 $\mu \mathrm{g} / \mathrm{mL}$ of fungizone. Each dilution $(25 \mu \mathrm{L})$ was placed in wells of a 96-well, flat-bottomed microtiter plate followed by the addition of an equal volume of virus suspension containing approximately 300 TCID $_{50}$ (i.e., $50 \%$ tissue culture infective dose) of BVDV-1 (Singer strain). The whey-virus mixture was incubated at $37^{\circ} \mathrm{C}$ for 60 min. A suspension of bovine turbinate cells $\left(5 \times 10^{5}\right.$ cells $/ \mathrm{mL}$ ) was then added to all wells at $50 \mu \mathrm{L}$ per well. A drop of mineral oil was also placed in all wells to minimize liquid evaporation. The plates were incubated at $37^{\circ} \mathrm{C}$ in a $5 \% \mathrm{CO}_{2}$ atmosphere for $7 \mathrm{~d}$. Each set of plates had cell controls and a virus back-titration control in addition to individual whey controls. Antibody titers were expressed as the reciprocal of the highest dilution that prevented the development of viral cytopathic effects. After BVDV SN titers were log transformed, a 2-tailed paired $t$-test was used to contrast the colostrum BVDV SN titers $\left[\log _{2}\right.$ (titer)] at each of the 15-min sampling points to the original BVDV SN titer measured in sample number 2 (postinoculation sample at $20^{\circ} \mathrm{C}$ ). Statistical significance was established at $P$ $<0.05$.

\section{RESULTS}

\section{Culture of Bacterial Pathogens from Colostrums}

For each of the 5 pathogens studied, the average results of bacterial recovery from the 4 replicate batches of heat-treated colostrum are presented in Table 1. For all 4 replicate batches, $M$. bovis was consistently not detected in colostrum samples collected upon reaching the target temperature of $60^{\circ} \mathrm{C}$, indicating the organism had not survived the 30-min heat-up phase (Table 1). For all 4 replicate batches, E. coli $\mathrm{O} 157: \mathrm{H} 7$ was consistently not detected in colostrum samples collected after 15 min of heating at $60^{\circ} \mathrm{C}$, and L. monocytogenes and $S$. enteritidis were consistently not detected in colostrum samples collected after $30 \mathrm{~min}$ of heating at $60^{\circ} \mathrm{C}(\mathrm{Ta}-$ ble 1).

Upon averaging the culture results from the 4 replicate batches of colostrum inoculated with Map, the organism was not detected after $60 \mathrm{~min}$ of heating at $60^{\circ} \mathrm{C}$ (Table 1). However, these results differed slightly from the results obtained for the other 4 pathogens, in that the duration of heat-treatment at $60^{\circ} \mathrm{C}$ required before Map could no longer be detected was not consistent across all 4 replicate batches. In particular, the third batch showed no detectable growth after heattreatment for $60 \mathrm{~min}$, but barely visible pinprick colonies (indicative of heat-treated Map and counted as less than $1 \mathrm{cfu} / \mathrm{mL}$ ) were detected in samples collected after heat-treatment for 75 and $90 \mathrm{~min}$ (Table 1). These pinprick colonies were confirmed as Map using PCR analysis.

\section{IgG Concentration and Activity in Colostrum}

Immunoglobulin $\mathrm{G}$ concentration results were available for 5 batches of colostrum heat-treated at $60^{\circ} \mathrm{C}$ for $120 \mathrm{~min}$. The mean IgG concentration was not different between raw colostrum $(60.5 \mathrm{mg} / \mathrm{mL} ; \mathrm{SD}=4.3$; range $=$ 54.8 to 65.8 ) and colostrum heated at $60^{\circ} \mathrm{C}$ for $120 \mathrm{~min}$ $(59.1 \mathrm{mg} / \mathrm{mL} ; \mathrm{SD}=1.9 ;$ range $=57.3$ to $61.8 ; P>0.05$; Figure 1). The mean percent reduction in IgG concentration for these 5 batches of moderate- to high-quality colostrum, after heating for $120 \mathrm{~min}$, was $2.2 \%$ (SD = $4.2 ;-4.4$ to 6.1 ).

Readers should be aware that IgG concentrations were measured for the additional 3 batches, but because IgG measurements for these latter 3 batches were not available beyond heating for $90 \mathrm{~min}$ in duration, they were not included in the final analysis or in Table 1. Nonetheless, even when they were included in the analysis (up to $90 \mathrm{~min}$ ), there was still no significant effect of heating on IgG concentration. However, it is worth noting that for 2 of these 3 batches that were of very high quality ( $>75 \mathrm{mg} / \mathrm{mL}$ of $\mathrm{IgG})$, a larger numerical percent reduction in IgG concentration was observed than occurred for the other batches. After heating at $60^{\circ} \mathrm{C}$ for $90 \mathrm{~min}$, the IgG concentration in batch M6 had dropped from 76.6 to $70.8 \mathrm{mg} / \mathrm{mL}$ ( $7.5 \%$ reduction) 
Table 1. Recovery of Mycoplasma bovis, Escherichia coli O157:H7, Salmonella enteritidis, Listeria monocytogenes, and Mycobacterium avium subsp. paratuberculosis (Map) from colostrum during heat-treatment at $60^{\circ} \mathrm{C}$ for $120 \mathrm{~min}$

\begin{tabular}{|c|c|c|c|c|c|c|c|c|c|c|c|c|}
\hline $\begin{array}{l}\text { Bacterial species } \\
(\text { inoculation dose, } \mathrm{cfu} / \mathrm{mL})^{1}\end{array}$ & \multicolumn{12}{|c|}{ Duration $(\min )$ at $60^{\circ} \mathrm{C}\left(\right.$ temperature, $\left.{ }^{\circ} \mathrm{C}\right)$} \\
\hline E. coli $\mathrm{O} 157: \mathrm{H} 7\left(1 \times 10^{6} \mathrm{cfu} / \mathrm{mL}\right)$ & ND & G & G & ND & ND & ND & ND & ND & ND & ND & ND & ND \\
\hline S. enteritidis $\left(1 \times 10^{6} \mathrm{cfu} / \mathrm{mL}\right)$ & ND & G & G & G & ND & ND & ND & ND & ND & ND & ND & ND \\
\hline L. monocytogenes $\left(1 \times 10^{6} \mathrm{cfu} / \mathrm{mL}\right)$ & ND & $\mathrm{G}$ & G & $\mathrm{G}$ & ND & ND & ND & ND & $\mathrm{ND}$ & ND & ND & ND \\
\hline M. paratuberculosis $\left(1 \times 10^{3} \mathrm{cfu} / \mathrm{mL}\right)$ & ND & G & G & G & G & G & ND & ND & ND & ND & ND & ND \\
\hline Map batch 3 & ND & $\mathrm{G}$ & $\mathrm{G}$ & $\mathrm{G}$ & ND & G & ND & $\mathrm{G}$ & G & ND & ND & $\mathrm{ND}$ \\
\hline Map batch 4 & ND & $\mathrm{G}$ & $\mathrm{G}$ & $\mathrm{G}$ & ND & $\mathrm{G}$ & ND & ND & ND & ND & ND & $\mathrm{ND}$ \\
\hline
\end{tabular}

${ }^{1}$ Results are averaged from 4 replicate runs. For Map, average values and individual values are presented. $\mathrm{C}=$ contaminated; $\mathrm{G}=$ growth detected; ND = growth not detected.

${ }^{2}$ Preinoculation sample (negative control); -30 represents a time point 30 min before the target temperature was reached.

${ }^{3}$ Postinoculation sample (positive control); -30 represents a time point $30 \mathrm{~min}$ before the target temperature was reached.

and the IgG concentration in batch M25 had dropped from 79.1 to $69.8 \mathrm{mg} / \mathrm{mL}$ ( $11.7 \%$ reduction).

Serum neutralization titers for anti-BVDV antibodies were available for 3 batches of colostrum heattreated at $60^{\circ} \mathrm{C}$ for $120 \mathrm{~min}$. The mean $\log _{2}(\mathrm{BVDV} \mathrm{SN}$ titer) was not different for raw colostrum samples (12.3; $\mathrm{SD}=0.58 ;$ range $=12.0$ to 13.0 ) compared with samples heated at $60^{\circ} \mathrm{C}$ for $120 \mathrm{~min}(12.0 ; \mathrm{SD}=0$; range $=12.0$ to $12.0 ; P>0.05$; Figure 1). Readers should be aware that SN titers for anti-BVDV antibodies were measured for 2 additional batches, but because results for these latter 2 batches were not available beyond heating for 75 min in duration, they were not included in the final analysis or in Table 1. Nonetheless, even when they

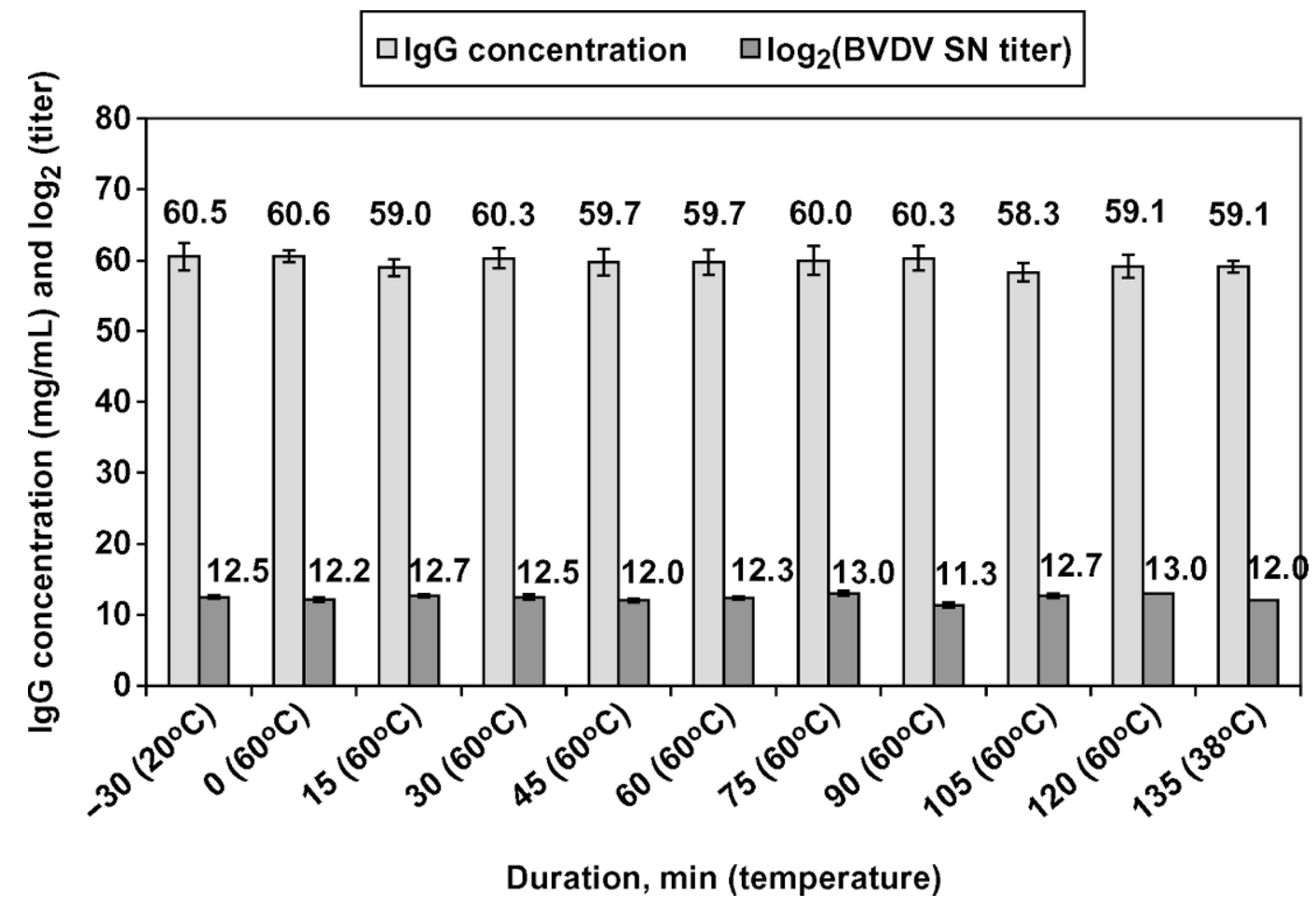

Figure 1. Mean $( \pm \mathrm{SE})$ IgG concentration (data from 5 batches of colostrum) and bovine viral diarrhea virus type 1 serum neutralization titer (BVDV SN titer; data from 3 batches of colostrum) in 30-L batches of colostrum during heat-treatment in a commercial on-farm batch pasteurizer at $60^{\circ} \mathrm{C}$ for $120 \mathrm{~min}$. 
were included in the analysis (up to $75 \mathrm{~min}$ ), there was still no reduction observed in antibody activity.

\section{DISCUSSION}

Pasteurization of colostrum could serve as an effective and practical method of reducing pathogen exposure to highly susceptible newborn calves, reducing the high rate of preweaning mortality (8.4 to 10.7\%) experienced in dairy replacement heifers in the United States (National Animal Health Monitoring System, 1993, 1996, 2002) as well as reducing the risk for transmitting specific economically important pathogens such as Map.

Although a considerable number of studies have investigated the effectiveness of pasteurization in destroying important pathogens in milk, far fewer studies have reported on the pasteurization of colostrum. Green et al. (2002) reported that bovine colostrum can be successfully pasteurized using either commercial batch pasteurization $\left(63^{\circ} \mathrm{C}\right.$ for $\left.30 \mathrm{~min}\right)$ or HTST pasteurization $\left(72^{\circ} \mathrm{C}\right.$ for $\left.15 \mathrm{~s}\right)$ systems to eliminate important bacterial pathogens including Salmonella spp., L. monocytogenes, and E. coli O157:H7. Stabel et al. (2004) reported that HTST pasteurization of colostrum using a commercial on-farm pasteurizer (at $71.7^{\circ} \mathrm{C}$ for $15 \mathrm{~s}$ ) was effective in destroying Map inoculated in colostrum at $10^{5} \mathrm{cfu} / \mathrm{mL}$. Meylan et al. (1995) reported that simulated batch-pasteurization of 50-mL volumes of colostrum, held at $63^{\circ} \mathrm{C}$ for $30 \mathrm{~min}$, effectively eliminated Map from colostrum samples that were inoculated with $10^{2}$ or $10^{3} \mathrm{cfu} / \mathrm{mL}$. However, viable Map was recovered from 2 of 6 pasteurized samples that were inoculated with $10^{4} \mathrm{cfu} / \mathrm{mL}$.

Past studies have suggested that pasteurization of colostrum using conventional methods can eliminate or significantly reduce exposure to pathogens. However, an important consequence of this procedure is that it results in increased viscosity, adversely affecting feeding and cleaning characteristics. In addition, there is significant denaturation of colostral Ig (Meylan et al., 1995; Godden et al., 2003; Green et al., 2003; Stabel et al., 2004), which in turn will produce lower serum IgG concentrations in newborn calves fed pasteurized colostrum (Godden et al., 2003).

However, this problem may be overcome by using a longer, lower-temperature approach to heat-treat colostrum. In a recent study, $50-\mathrm{mL}$ volumes of bovine colostrum were successfully heat-treated in a Rapid Visco Analyzer at $60^{\circ} \mathrm{C}$ for as long as $120 \mathrm{~min}$ without causing increases in viscosity or reductions in IgG concentration (McMartin et al., 2006). Although these results appeared to be extremely promising, the authors still needed to verify whether the same results could be achieved with large volumes of colostrum that were similarly heat-treated when using a commercial onfarm batch pasteurization system. Furthermore, they needed to describe the duration of heating necessary at $60^{\circ} \mathrm{C}$ to eliminate important bacterial pathogens.

The results of this study showed that large (30-L) batches of moderate- to high-quality colostrum can be successfully heat-treated at $60^{\circ} \mathrm{C}$ in a commercial onfarm batch pasteurization system for at least $120 \mathrm{~min}$ without reducing the IgG concentration $(\mathrm{mg} / \mathrm{mL})$ or activity $\left[\log _{2}\right.$ (BVDV SN titer)]. Our results agreed with an earlier study (McMartin et al., 2006) in that very high quality colostrum $(>75 \mathrm{mg} / \mathrm{mL})$ suffered a greater absolute percent numerical reduction in IgG concentration (mean reduction of $9.6 \%$ ) than did moderate- to high-quality colostrum $(<75 \mathrm{mg} / \mathrm{mL}$; nonsignificant numerical reduction of $2.2 \%$ ). However, the authors feel that a $10 \%$ reduction in IgG concentration is of no practical importance because the end product is still of exceptionally high quality (i.e., a very high quality sample can afford to experience a 10\% reduction in IgG concentration and still remain a very high quality sample to feed to calves).

This study also demonstrated that heat-treating large (30-L) batches of colostrum in a commercial onfarm batch pasteurization system at $60^{\circ} \mathrm{C}$ for $30 \mathrm{~min}$ should be adequate to eliminate high concentrations of L. monocytogenes, E. coli O157:H7, S. enteritidis, and $M$. bovis. If these results can be achieved on commercial dairy farms, then the most immediate benefit from feeding heat-treated colostrum may be to reduce enteritis caused by fecal coliforms, as well as to prevent transmission of other economically important pathogens such as Salmonella and Mycoplasma spp. Finally, if the hypothesis is true that living bacteria in colostrum may interfere with passive absorption of colostral antibodies, then feeding heat-treated colostrum could help improve passive transfer of IgG in calves (James and Polan, 1978; James et al., 1981; Staley and Bush, 1985).

In addition to the potential short-term benefits described, producers will also be very interested to know whether feeding heat-treated colostrum could serve as a potential control point in a comprehensive Johne's disease control program. Although the results of this research were less consistent for Map than for the other 4 pathogens studied, when averaging the results from all 4 replicate batches, the authors' interpretation of the results was that heating at $60^{\circ} \mathrm{C}$ for $60 \mathrm{~min}$ should be sufficient to eliminate Map under most conditions, because the results from batch 3 were not repeatable. However, it is important not to dismiss the variability observed in the Map culture results. The accuracy (especially sensitivity) of the sampling and culture methods used may be one factor contributing to the variabil- 
ity observed in our results. For example, for batch 3 the sample collected after 60 min yielded no detectable growth, even though the samples collected after 75 and 90 min yielded detectable growth (but at very small concentrations). Similar observations (but at earlier time points) were observed in batches 2 and 4 . Although the current results suggest that heating at $60^{\circ} \mathrm{C}$ for 60 min should be sufficient to eliminate Map in most situations, these findings should be further investigated to determine whether they can be replicated by additional studies.

One factor readers should consider when interpreting the Map culture results from this or any other study is the inoculation dose used. Inoculum concentrations used for all pathogens in this study were selected to meet or exceed concentrations of the organism that might be expected to exist in naturally infected colostrum under field conditions. The inoculation dose for Map used in the study $\left(10^{3} \mathrm{cfu} / \mathrm{mL}\right)$ was considerably higher than concentrations known to be cultured from milk or colostrum of naturally shedding Johne's-infected cows (5 to $8 \mathrm{cfu} / 50 \mathrm{~mL}$ of milk; Taylor et al., 1981; Sweeney et al., 1992). Thus, and precluding significant fecal contamination of colostrum during the harvest, storage, or feeding processes, we would expect that concentrations of Map found in naturally infected colostrum on commercial dairy farms should be significantly lower than those used in this study, lending confidence to the conclusion that heat-treatment at $60^{\circ} \mathrm{C}$ for 60 min should be sufficient to control the transmission of this organism in most situations. Also, it is still undetermined whether low concentrations of the organism fed in a single feeding of colostrum could represent an infective dose to a newborn calf. Thus, if heat-treatment of colostrum at $60^{\circ} \mathrm{C}$ for $60 \mathrm{~min}$ can eliminate, or at least significantly reduce, the concentration of viable Map in colostrum, then adoption of the practice of feeding heattreated colostrum could prove to be an effective means of preventing, or at least reducing, the transmission of Map on commercial dairy farms. However, these questions require further investigation.

This work was done on colostrum that was collected, frozen, thawed, inoculated with potential pathogens, and then pasteurized, although we would expect similar results with fresh colostrum. The results of this research are very promising; however, these studies have thus far been confined to a controlled laboratory setting, and many questions remain to be investigated. For example, even though this longer, lower-temperature approach may not harm the colostral antibody concentration or activity, it has yet to be determined whether the heat-treatment process can harm other important immune factors found in colostrum (e.g., vitamins, white blood cells). Furthermore, large-scale prospective controlled field studies will be needed to 1) describe whether the practice of feeding heat-treated colostrum can be successfully adopted on commercial dairy farms without interfering with passive transfer in calves, 2) describe and quantify any short-term or long-term health or performance benefits in calves fed heattreated colostrum (e.g., reduced preweaning morbidity and mortality, improved growth rates, reduced transmission of Map), and finally, 3) describe and quantify whether there is any economic benefit from feeding heat-treated colostrum on commercial dairy farms (e.g., cost-benefit and break-even analyses).

\section{CONCLUSIONS}

Large (30-L) batches of moderate- to high-quality bovine colostrum can be heat-treated in a commercial onfarm batch pasteurizer at $60^{\circ} \mathrm{C}$ for at least $120 \mathrm{~min}$ without affecting the IgG concentration or activity. $M y$ coplasma bovis, L. monocytogenes, E. coli $\mathrm{O} 157: \mathrm{H} 7$, and $S$. enteritidis added to colostrum could not be recovered after colostrum was heat-treated at $60^{\circ} \mathrm{C}$ for $30 \mathrm{~min}$. Heat-treatment at $60^{\circ} \mathrm{C}$ for $60 \mathrm{~min}$ should be sufficient to eliminate Map from colostrum in most situations. However, the latter findings should be further investigated to determine whether they can be replicated by additional studies. Further research is also needed to determine whether these results can be replicated on commercial dairy farms, and to describe any health performance or economic benefits that may come from feeding heat-treated colostrum on commercial dairy farms.

\section{ACKNOWLEDGMENTS}

We thank USDA Animal and Plant Health Inspection Service-Veterinary Services and the University of Minnesota Merck-Merial Summer Scholars Program for their financial support of this research.

\section{REFERENCES}

Clark, R. C., S. A. McEwen, V. P. Gannon, H. Lior, and C. L. Gyles. 1989. Isolation of verocytotoxin-producing Escherichia coli from milk filters in Southwestern Ontario. Epidemiol. Infect. 102:253-260.

Davis, C. L., and J. K. Drackley. 1998. The Development, Nutrition, and Management of the Young Calf. 1st ed. Iowa State University Press, Ames.

Etzel, L. R., R. E. Strohbehn, and J. K. McVicker. 1997. Development of an automated turbidometric immunoassay for quantification of bovine serum immunoglobulin G. Am. J. Vet. Res. 48:1201-1205.

Farber, J. M., G. W. Sanders, and S. A. Malcolm. 1988. The presence of Listeria spp. in raw milk in Ontario. Can. J. Microbiol. 34:95-100.

Giles, N., S. A. Hopper, and C. Wray. 1989. Persistence of S. typhimurium in a large dairy herd. Epidemiol. Infect. 103:235-241.

Godden, S. M., S. Smith, J. M. Feirtag, L. R. Green, S. J. Wells, and J.P. Fetrow. 2003. Effect of on-farm commercial batch pasteuriza- 
tion of colostrum on colostrum and serum immunoglobulin concentrations in dairy calves. J. Dairy Sci. 86:1503-1512.

Green, L., S. Godden, and J. Feirtag. 2002. Pasteurization effects on Mycobacterium paratuberculosis, E. coli O157:H7, Salmonella sp., Listeria monocytogenes, and Staphylococcus aureus. Page 190 in Proc. 35th Annu. Convention Am. Assn. Bovine Pract., Madison, WI. Am. Assoc. Bovine Pract., Stillwater, OK.

Green, L., S. Godden, and J. Feirtag. 2003. Effect of batch and high temperature-short time pasteurization on immunoglobulin G concentrations in colostrum. J. Dairy Sci. 86(Suppl. 1):246. (Abstr.)

James, R. E., and C. E. Polan. 1978. Effect of orally administered duodenal fluid on serum proteins in neonatal calves. J. Dairy Sci. 61:1444-1449.

James, R. E., C. E. Polan, and K. A. Cummins. 1981. Influence of administered indigenous microorganisms on uptake of [Iodine125] $\gamma$-Globulin in vivo by intestinal segments of neonatal calves. J. Dairy Sci. 64:52-61.

Lovett, J., D. W. Francis, and J. M. Hunt. 1983. Isolation of Campylobacter jejuni from raw milk. Appl. Environ. Microbiol. 46:459-462.

McEwen, S. A., W. Martin, R. C. Clarke, and S. E. Tamblyn. 1988. A prevalence survey of Salmonella in raw milk in Ontario, 198687. J. Food Prot. 51:963-965.

McGuirk, S., and M. Collins. 2004. Managing the production, storage and delivery of colostrum. Pages 593-603 in Veterinary Clinics of North America—Food Animal Practice. Vol. 20. W.B. Saunders, New York, NY.

McMartin, S., S. Godden, L. Metzger, J. Feirtag, R. Bey, J. Stabel, S. Goyal, J. Fetrow, S. Wells, and H. Chester-Jones. 2006. Heattreatment of bovine colostrums. I: Effects of temperature on viscosity and immunoglobulin G level. J. Dairy Sci. 89:2110-2118.

McVicker, J. K., G. C. Rouse, M. A. Fowler, B. H. Perry, B. L. Miller, and T. E. Johnson. 2002. Evaluation of a lateral-flow immunoassay for use in monitoring passive transfer of immunoglobulins in calves. Am. J. Vet. Res. 63:247-250.

Meylan, M., M. Rings, W. P. Shulaw, J. J. Kowalski, S. Bech-Nielsen, and G. F. Hoffsis. 1996. Survival of Mycobacterium paratuberculosis and preservation of immunoglobulin $\mathrm{G}$ in bovine colostrum under experimental conditions simulating pasteurization. Am. J. Vet. Res. 57:1580-1585.

National Animal Health Monitoring System (NAHMS). 1993. National Dairy Heifer Evaluation Project. Pages 5-10 in Dairy Heifer Morbidity, Mortality, and Health Management Practices
Focusing on Preweaned Heifers. USDA Animal and Plant Health Inspection Service-Veterinary Services, Ft. Collins, CO.

National Animal Health Monitoring System (NAHMS). 1996. Pages 17-20 in Dairy 1996. Part II: Changes in the U.S. Dairy Industry: 1991-1996. USDA Animal and Plant Health Inspection ServiceVeterinary Services, Ft. Collins, CO.

National Animal Health Monitoring System (NAHMS). 2002. Pages 57-58 in Dairy 2002. Part I: Reference of Dairy Health and Management in the United States. USDA Animal and Plant Health Inspection Service-Veterinary Services, Ft. Collins, CO.

Poulsen, K. P., F. A. Hartmann, and S. M. McGuirk. 2002. Bacteria in colostrum: Impact on calf health. Page 773 (Abstr. 52) in Proc. 20th Am. Coll. Intern. Vet. Med., Dallas, TX. Am. Coll. Intern. Vet. Med., Lakewood, Co.

Stabel, J. R., S. Hurd, L. Calvente, and R. F. Rosenbusch. 2004. Destruction of Mycobacterium paratuberculosis, Salmonella spp., and Mycoplasma spp. in raw milk by a commercial on-farm hightemperature, short-time pasteurizer. J. Dairy Sci. 87:2177-2183.

Stabel, J. R., and A. Lambertz. 2004. Efficacy of pasteurization conditions for the inactivation of Mycobacterium avium subsp. paratuberculosis in milk. J. Food Prot. 67:2719-2726.

Staley, T. E., and L. J. Bush. 1985. Receptor mechanisms of the neonatal intestine and their relationship to Ig absorption and disease. J. Dairy Sci. 68:184-205.

Steele, M. L., W. B. McNab, C. Poppe, M. W. Griffiths, S. Chen, S. A. Degrandis, L. C. Fruhner, C. A. Larkin, J. A. Lynch, and J. A. Odumeru. 1997. Survey of Ontario bulk tank raw milk for food-borne pathogens. J. Food Prot. 60:1341-1346.

Streeter, R. N., G. F. Hoffsis, S. Bech-Nielsen, W. P. Shulaw, and D. M. Rings. 1995. Isolation of Mycobacterium paratuberculosis from colostrum and milk of subclinically infected cows. Am. J. Vet. Res. 56:1322-1324.

Sweeney, R. W., R. H. Whitlock, and A. E. Rosenberger. 1992. Mycobacterium paratuberculosis cultured from milk and supramammary lymph nodes of infected asymptomatic cows. J. Clin. Microbiol. 30:166-171.

Taylor, T. K., C. R. Wilks, and D. S. McQueen. 1981. Isolation of Mycobacterium paratuberculosis from the milk of a cow with Johne's disease. Vet. Rec. 109:532-533.

Walz, P. H., T. P. Mullaney, J. A. Render, R. D. Walker, T. Mosser, and J. C. Baker. 1997. Otitis media in preweaned Holstein dairy calves in Michigan due to Mycoplasma bovis. J. Vet. Diagn. Invest. 9:250-254. 